\title{
Stroke: Timing isn't everything
}

7 he stroke medicine of 2013 is very different from the academically elegant but diagnostically challenged and therapeutically impotent discipline of the past.

With advances come controversies, new questions and insights, and the challenge to diffuse advances worldwide. In this issue of Neurology: Clinical Practice, several articles address representative examples of these issues.

Fugate and Rabinstein point out that in addition to a narrow temporal treatment window, administration of recombinant tissue plasminogen activator (rtPA) to acute ischemic stroke patients is limited by extensive additional exclusion criteria. They critically analyze existing evidence that supports and refutes current contraindications for administering IV rtPA (p. 177).

Imaging can be deceiving. Watts et al. retrospectively examined a large population of stroke patients and identify stroke syndromes associated with diffusion-weighted imaging-negative MRI (p. 186).

Risk factors, particularly those that are potentially modifiable, are an important avenue of research and treatment to prevent initial or recurrent stroke. Davis et al. discuss the relationship between obstructive sleep apnea and stroke (p. 192).

In a Practice Across Borders series on stroke, neurologists from Australia, Brazil, China, Egypt, Finland, and the United States discuss the standard approach to assessment and implementation of therapeutic strategies for acute stroke within the tissue plasminogen activator therapeutic window in their respective countries (p. 202). Culebras and Chaturvedi, curators of the series, provide additional commentary, drawing attention to similarities and differences in these approaches. We further discuss the series in an interview with the curators recorded live at the 2013 American Academy of Neurology annual meeting in San Diego.

We welcome your feedback on these articles and seek your own practical, real-world experience.
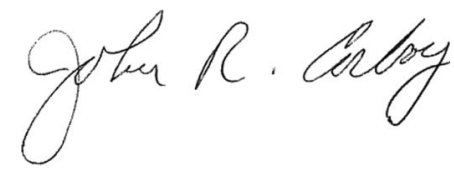

John R. Corboy, MD, FAAN

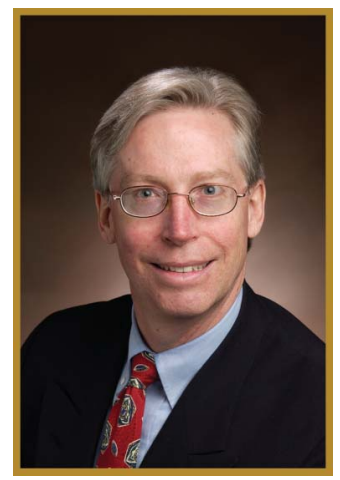




\title{
Neurology ${ }^{\circ}$ Clinical Practice
}

\author{
Stroke: Timing isn't everything \\ Neurol Clin Pract 2013;3;175 \\ DOI 10.1212/CPJ.0b013e31829723ca
}

This information is current as of June 10, 2013

\section{Updated Information \& Services}

Permissions \& Licensing

Reprints including high resolution figures, can be found at:

http://cp.neurology.org/content/3/3/175.full.html

Information about reproducing this article in parts (figures,tables) or in its entirety can be found online at:

http://cp.neurology.org/misc/about.xhtml\#permissions

Information about ordering reprints can be found online: http://cp.neurology.org/misc/addir.xhtml\#reprintsus

Neurol Clin Pract is an official journal of the American Academy of Neurology. Published continuously since 2011, it is now a bimonthly with 6 issues per year. Copyright ( 2013 American Academy of Neurology. All rights reserved. Print ISSN: 2163-0402. Online ISSN: 2163-0933.

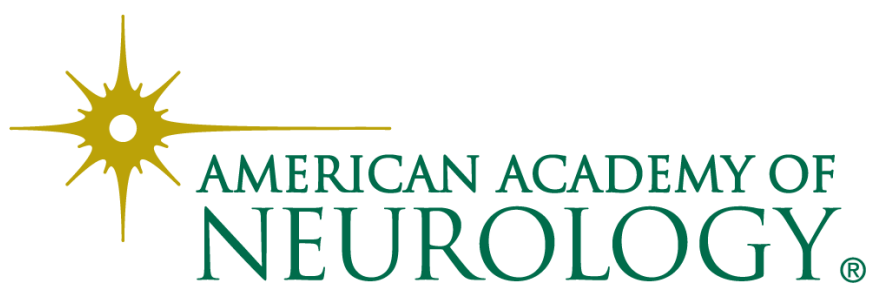

